\section{Chronology of Collaboration}

December 7,1959 . US offer of help in tracking Russian manned flights-Russians reply that they would ask for help "if the need arose".

March 7, 1962. Exchange of tracking and data acquisition stations declined.

September 20, 1962. No response to Kennedy's offer in the UN General Assembly for joint exploration of the Moon.

December 8, 1964. Proposed exchange visits to deep space tracking stations declined on the grounds that such visits were impossible.

May 3, 1965. No response to NASSA suggestion of telecommunications experiments with Molniya I.

August 25, 1965. Invitation to launching of Gemini VI declined.

November 16, 1965. Further enquiry about the use of Molniya-1 declined by the Soviet Union as being impossible "in the present conditions".

January 6, 1966. Academician Blagonravov declined request for information about Russian experiments on Venus probe "to emphasize experiments which could complement rather than duplicate Soviet work" on the grounds that he had no authority to give the information.

November 11, 1966. Invitation to the launching of Gemini XII declined.

March 27, 1967. American request for advance information of soil analysis from Luna 13 met only after formal publication.

March 27, 1967. Proposals for small meetings between the Russian and American academies on weather prediction, planetary research and orbiting telescopes so far ignored.

June 2, 1967. Proposal for London meeting on cxchange of weather data, specified under the agreement of 1962, denied-"the required semiannual meetings have not been held since October 1965".

December 19, 1967. Proposal by Dr F. Seitz, then president of the US National Academy of Sciences, for a joint working party on Venus experiments accepted in principle on January 24, 1968 , but "there has been no further Soviet response".

May 29, 1969. Invitation to Apollo 11 declined.

August 21, 1969. Invitation to planning meeting of Viking rockets to Mars declined on the grounds of lack of time (from September 3-11).

September 18, 1969. Proposal for exchange of biomedical scientists pending for further consultation in the Sovict Union.

October 3, 1969. Offer of lunar samples not taken up.

October 10, 1969. Academician Keldysh declined invitation of proposals for Soviet expcriments on NASA space rockets but said that NASA and the Soviet academy should "coordinate planetary goals and exchange results of unmanned planetary investigations".

December 18,1969 . No response to invitation to Houston lunar conference.

January 29, 1970. Invitation to discussion of United States earth resources satellites declined.

\section{INTELSAT}

\section{Agreement Snatched Away}

\section{from our Special Correspondent}

Sometrmes international conferences end not with a whimper but with a bang. This final week of the conference to decide on a permanent structure for Intelsat, the worldwide satellite system, began with such ferocity that the members had to retreat into private session, taking with them all the glowing press cuttings of last weekend, which had them breaking their year-long deadlock and reaching accord.

The dog in the manger once again seems to have been Comsat, the American satellite corporation, which has run Intelsat very nicely, thank you, without undue interference from its other so-called partners in the international consortium, since 1964. Comsat had seemed to be losing ground. The United States State Department surrendered first of all Comsat's majority role in the consortium and then, last week, gave away Comsat's claim to hold the managership permanently. The State Department agreed to what is called "internationalizing the managership" and decided instead to allow Comsat to hold the jobwhere the real power is-for six more years only. When the conference broke up at the weekend, delegates believed that they had agreed to agree on a compromise engineered by those two powerful nations least concerned with le défi américain, Japan and Australia. But when the agreement emerged on Monday morning in new clothes, dressed up in treaty language, it did not look the samc at all. The director general, the executive who was supposed to choose a new manager when Comsat's term ended, was in plain language, emasculated.

None among the 74 delegations was really happy; there was, early in the week, no telling how it would all end. The tiny nations were particularly downcast. They have not won very much at all from the various bits of horse trading. And what they wanted was not so very much-to have their satellite ground stations counted as investment in Intelsat (instead of having their investment measured only by the amount of traffic that they sent through the system). What they also wanted, and may still be willing to fight for, was a kind of general assembly in which they had genuine power. As it looks now, the Intelsat assembly will have to be content with having one formal session, at which the main business will be to decide when they shall meet again.

Comsat will probably be manager for at least six more years, during which the next major round of contracts for a new generation of satellites will be handed out. But during that time Comsat will probably be supervised by a potent board of governors and an alert and non-American secretary general to look over its shoulder as it chooses satellite designs and dispenses Intelsat's money. The British-European bloc, while far from jubilant, is not miserable either. Its efforts and eloquence have been instrumental in demoting Comsat, something which seemed impossible two years ago. There is also general pleasure that the cumbersome conference which opened more than two years ago is crawling to a close. If the agreement that emerges is inelegant, it will nonetheless be both international and commercial and that is no small accom. plishment. 